\title{
Peningkatan Potensi Ikan Baji - Baji (Grammoplites scaber) Dan Proporsi Bagian Tubuh Sebagai Sumber Bahan Baku
}

\author{
Improvement of Potential From Proportion of Baji-Baji Fish (Grammoplites Scaber) \\ from As A Source of Raw Materials \\ Ayu Diana*, Ahmad Fauzan Lubis \\ Program Studi Teknologi Pengolahan Hasil Perikanan, Politeknik Tanjungbalai \\ Jl. Sei Raja Kelurahan Sei Raja Kecamatan Sei Tualang Raso Kota Tanjungbalai, Indonesia \\ *Email: ayudianatip2012@gmail.com
}

\begin{abstract}
ABSTRAK
Ikan baji- baji mampu sebagai bahan pangan yang merupakan sumber zat gizi yang penting bagi proses kelangsungan hidup manusia. Tujuan yaitu perlu adanya upaya dalam peningkatan potensi ikan baji-baji ini melalui pengkajian analisis komposisi kimianya. Metode yang digunakan adalah metode eksperimen dengan 3 (tiga) perlakukan dan tiga kali ulangan. Perlakukan yang digunakan yaitu perbandingan ikan baji-baji dari bagian yang berbeda yaitu kepala, badan, ekor dengan rancangan acak lengkap (RAL) non faktorial. Pengamatan yang dilakukan adalah analisa komposisi kimia (proksimat). Ikan baji-baji memiliki kandungan kadar air 64\%, protein 15\%, kadar lemak 6\%, kadar abu 5\%, dan karbohidrat 10\%. Proporsi bagian tubuh pada ikan memiliki keunggulan pada setiap bagiannya yaitu protein pada truncus $(15,97 \%)$, lemak pada truncus $(10,40 \%)$, karbohidrat pada cauda $(12,55 \%)$. Ikan baji-baji merupakan produk yang relatif murah namun memiliki kandungan gizi yang baik untuk dikonsumsi, dari peningkatan potensi ikan baji-baji ini memiliki kandungan gizi yang hamper sama dengan kandungan gizi ikan komersil lainnya.
\end{abstract}

Kata Kunci: Ikan baji-baji, Komposisi kimia, Proporsi tubuh

\begin{abstract}
Baji-baji fish is able to fish as a food that is a source of nutrients that are important to the process of human survival. The purpose of that is need for efforts in increasing the potential fish wedge-wedge through the study of its chemical composition analysis. The method used is the method of experiments with three (3) three-time treat and deuteronomy. Treat is a comparison of fish from different sections namely caput, truncus, cauda with a complete random design (RAL) non factorial. Observations made was the analysis of the chemical composition (proximat). Baji-baji fish contain moisture content (64\%), protein (15\%), lipids (6\%), ash (5\%), and carbohydrate $(10 \%)$. The proportion of body parts on a fish advantage on any part of it that is a protein (truncus, 15.97\%), lipids (truncus, 10.40\%), carbohydrates (cauda, 12.55\%). Baji-baji fish is a relatively cheap products but have a good nutrient content for consumption, of the increase in potential fish baji-baji has a similar nutritional content with other commercial fish nutrient content.
\end{abstract}

Keywords: Baji - baji fish, Chemical composition, Proportions of body 


\section{A. PENDAHULUAN}

Potensi sektor perikanan yang utama didukung oleh perikanan laut berupa hasil penangkapan ikan, kerang dan udang. Menurut Badan Pusat Statistik (2017) daerah tanjungbalai merupakan salah satu sentra perikanan terbesar di Sumatera Utara dengan produksi perikanan laut $34.643,70$ ton, darat (perairan umum) 16,97 ton, budidaya 107,20 ton. Beragam jenis ikan dan udang hasil tangkapan nelayan di Tanjungbalai sebagian besar diekspor. Sehari ikan yang diekspor sekitar 12 ton. Ikan yang diekspor tersebut merupakan ikan dengan kualitas terbaik yakni ikan gembung, guring, cencaru, bawal, senangin, pekco gerapu, udang, dan kepiting (Metro, 2017). Selain jenis ikan bernilai komersil terdapat juga ikan hasil tangkapan nelayan kota tanjungbalai yang hanya dijual secara lokal ikan non komersil yang umumnya adalah yaitu ikan rucah, ikan biji nangka, ikan tamban, ikan gulamah, dan ikan baji-baji.

Ikan baji-baji (Grammoplites scaber) merupakan salah satu komoditas yang strategis untuk memenuhi kebutuhan protein yang relatif murah. Ikan memegang peranan penting dalam pemenuhan sumber gizi dan keamanan hidup bagi manusia pada negara berkembang (Gandotra et al., 2012). Ikan merupakan salah satu sumber zat gizi penting bagi proses kelangsungan hidup manusia. Manusia telah memanfaatkan ikan sebagai bahan pangan sejak beberapa abad yang lalu. Sebagai bahan pangan, ikan mengandung zat gizi utama berupa protein, lemak, vitamin dan mineral (Nurjanah, 2011).

Ikan mengandung protein yang tinggi. Protein pada ikan selain merupakan sumber nutrisi juga memiliki sifat fungsional yang penting untuk kesehatan (Chasanah et al, 2015). Protein merupakan suatu zat makanan yang amat penting bagi tubuh karena zat ini disamping berfungsi sebagai bahan bakar dalam tubuh juga berfungsi sebagai zat pembangun dan pengatur. Protein adalah sumber asamasam amino yang mengandung unsur-unsur $\mathrm{C}$, $\mathrm{H}, \mathrm{O}$ dan $\mathrm{N}$ yang tidak memiliki oleh lemak atau karbohidrat (Winarno, 2004).

Jenis ikan yang mengandung protein tinggi yaitu tuna, tenggiri, kurisi dan jenis ikan laut lainnya (cod, coalfish, haddock, red fish, catfish, plaice, halibut, ling, tosrk, dan mackerel). Ikan ikan tersebut sangat komersil dan termasuk jenis ikan kualitas eksport yang sangat diminati karena rasa dan rupa yang menarik. Jenis ikan lain yang mengandung protein tinggi dan memiliki albumin tinggi adalah ikan gabus. Menurut Harianti (2011) ikan gabus merupakan ikan yang tidak diminati karena memiliki rupa yang jelek dan baunya juga amis yang membuat tidak semua orang menyukainya, namun perhatian terhadap ikan gabus semakin meningkat sejak tahun 1990-an karena manfaat ikan gabus yang tidak lagi hanya sebagai ikan konsumsi, tetapi juga digunakan dalam pengobatan. Berbagai penelitian tentang ikan sebagai makanan berprotein yang baik untuk kesehatan yang mampu meningkatkan nilai komersil ikan telah banyak dilakukan berbagai pengujian terutama pada komposisi kimia dan kandungan gizi ikan.

Penelitian yang dilakukan Asfar et al (2014) semakin tingginya nilai komersil ikan gabus karena kandungan yang dimilikinya telah terbukti secara klinis pada beberapa penyakit, Ikan Gabus memiliki kandungan protein yang tinggi terutama albumin dan asam amino esensial, lemak khususnya asam lemak esensial, mineral khususnya zink/seng (Zn) dan beberapa vitamin yang sangat baik untuk kesehatan. Seperti hal nya dengan ikan gabus, ikan baji - baji juga merupakan ikan yang kurang diminati karena memiliki rupa yang jelek dan bau amis. Perlu adanya upaya dalam peningkatan potensi ikan baji-baji.

Menurut Pamijiati (2009) menjelaskan juga bahwa ikan banyak digemari oleh sebagian besar masyarakat Indonesia karena memiliki kandungan gizi tinggi dan protein yang lengkap dan penting untuk tubuh. Zat gizi utama pada ikan antara lain protein, lemak, vitamin dan mineral. Dengan demikian dilakukan pengkajian peningkatan potensi ikan baji - baji sebagai sumber bahan baku produk pangan terhadap komposisi kimia dan kandungan asam amino. Keanekaragaman hasil ikani tersebut dapat memberikan suatu nilai tambah bagi masyarakat bila dipasarkan baik dalam bentuk segar, olahan setengah jadi ataupun olahan dalam bentuk jadi. Bahan baku yang dapat digunakan dalam proses pengolahan ikan adalah ikan baji-baji (Pertiwi et al, 2015).

Setiap bagian tubuh ikan baji- baji memiliki proporsi yang berbeda berdasarkan pada ukuran tubuh dari ikan baji-baji tersebut sehingga setiap bagian ikan dapat dimanfaatkan sesuai dengan manfaatnya. Penelitian ini 
bertujuan untuk menentukan proporsi bagianbagian tubuh ikan dan mengetahui komposisi kimia (proksimat) ikan baji-baji, serta meningkatkan potensi ikan baji-baji sebagai produk pangan yang memiliki nilai komersil.

\section{B. METODOLOGI}

\section{Bahan dan Alat}

Bahan yang digunakan adalah ikan baji baji, BSA (Bovine Serum Albumin), $\mathrm{CuSO}_{4}$, metil merah, Brom Cresol Green, $\mathrm{K}_{2} \mathrm{SO}_{4}, \mathrm{H}_{3} \mathrm{BO}_{3}, \mathrm{HCl}$, $\mathrm{H}_{2} \mathrm{SO}_{4}, \mathrm{NaCl}, \mathrm{KOH}$, asam asetat glasial, kloroform, $\mathrm{KI}, \mathrm{Na}_{2} \mathrm{~S}_{2} \mathrm{O}_{3}$, phenolptalein, Heksana, Alkohol 96\%, $\mathrm{H}_{2} \mathrm{SO}_{4}, \mathrm{NaOH}$.

Alat yang digunakan adalah neraca analitik, mantel penangas, evaporator, desikator, aluminium foil, beaker glass, corong pisah, ball pipet, autoclave, buret, corong, erlenmeyer, gelas ukur, kantong plastik, labu kjeldahl, mortar dan stamper, $\mathrm{pH}$ meter, pipet tetes, pipet pasteur, pipet mohr, pisau, satu set alat LC-MS.

\section{Rancangan Penelitian}

Metode penelitian ini adalah metode expriment. Rancangan yang digunakan adalah Rancangan Acak Lengkap Non Faktorial (RAL) dengan tiga taraf perlakuan terhadap pembagian tiga bagian tubuh yang berbeda (kepala, badan, dan ekor) pada ikan baji-baji dengan ulangan sebanyak 3 kali, sehingga terdapat 9 unit percobaan. Parameter yang diamati adalah analisa proksimat meliputi kadar air, kadar abu, protein, lemak, dan karbohidrat. Penjabaran pembahasan melalui metode deskriptif yaitu menggambarkan serta menjelaskan kajian teori yang sifatnya konseptual melalui penelusuran pustaka, mengumpulkan literatur dari berbagai sumber pustaka, seperti buku, jurnal, artikel dari internet, dan sumber pustaka lainnya yang berkaitan dengan tulisan ini. Kandungan nilai gizi ikan baji-baji dapat diketahui melalui pengujian proksimat terdiri dari pengujian kadar air, kadar abu, protein, lemak, dan karbohidrat berdasarkan metode AOAC.

\section{Pelaksanaan Penelitian}

Bagan penelitian dilakukan dalam tiga tahap, yaitu: (1) preparasi sampel; (2) pembagian sampel dalam tiga bagian tubuh; (3) analisa komposisi kimia (proksimat).

\section{HASIL DAN PEMBAHASAN}

\section{Komposisi Kandungan Kimia Ikan Ikan Baji- Baji}

Ikan merupakan salah satu sumber zat gizi penting bagi proses kelangsungan hidup manusia. Manusia telah memanfaatkan ikan sebagai bahan pangan sejak beberapa abad yang lalu. Sebagai bahan pangan, ikan mengandung zat gizi utama berupa protein, lemak, vitamin dan mineral (Nurjanah et al, 2011). Ikan bajibaji (Grammoplites scaber L) memiliki warna tubuh bagian atas coklat dan bagian bawah berwarna terang. Bentuk kepala dan tubuh picak dengan tubuh dan ekor pada bagian atas tertutup sisik ktenoid yang kecil dan sisik sikloid pada bagian bawah yang datar.

Ikan baji-baji merupakan salah satu komoditas yang strategis untuk memenuhi kebutuhan protein yang relatif murah. Ikan bajibaji mampu sebagai bahan pangan, merupakan sumber zat gizi yang penting bagi proses kelangsungan hidup manusia. Adapun komposisi kimia ikan baji-baji dapat dilihat pada (gambar 1).

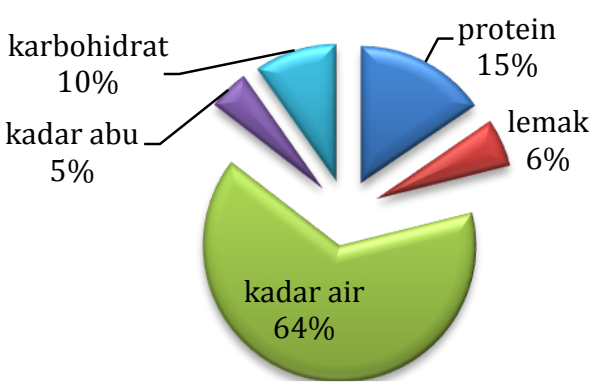

Gambar 1 Komposisi Kimia Ikan Baji - baji

Berdasarkan gambar di atas diketahui bahwa ikan baji-baji memiliki kandungan protein sebesar $15 \%$, lemak $6 \%$, dan didominasi oleh kadar air sebesar 64\%. Ikan baji-baji sebagai sumber bahan baku perlu penanganan segera setelah ditangkap karena kadar airnya yang cukup tinggi. ikan baji-baji (Grammoplites scaber) dalam potensinya sebagai bahan baku yang dapat digunakan dalam proses pengolahan terdapat berbagai cara yang digunakan untuk menentukan kualitas bahan bakunya sebagai produk pangan. Secara garis besar penentuan kualitas dapat dilakukan secara fisik, kimia dan biologis, namun umumnya penentukan kualitas bahan makanan akan mempertimbangkan kualitas bahan baku dari segi kandungan protein, lemak atau kandungan zat makanan. 


\section{Proporsi Bagian Tubuh Ikan Baji-baji terhadap Komposisi Kimia}

Proporsi bagian tubuh ikan baji - baji seperti pada tubuh ikan umumnya terbagi tiga bagian yaitu 1. Caput / bagian pada kepala, 2 . Truncus / bagian badan, dan 3. Cauda / bagian ekor. Menurut Anjarsari (2010) tubuh ikan pada umumnya terbagi atas tiga bagian, yaitu: 1) Caput: bagian kepala, yaitu mulai dari ujung moncong terdepan sampai dengan ujung tutup insang paling belakang. Pada bagian kepala terdapat mulut, rahang atas, rahang bawah, gigi, sungut, hidung, mata, insang, tutup insang, otak, jantung, dan sebagainya. 2) Truncus: bagian badan, yaitu mulai dari ujung tutup insang bagian belakang sampai dengan permulaan sirip dubur. Pada bagian badan terdapat sirip punggung, sirip dada, sirip perut, serta organorgan dalam seperti hati, empedu, lambung, usus, gonad, gelembung renang, ginjal, limpa, dan sebagainya. 3) Cauda: bagian ekor, yaitu mulai dari permulaan sirip dubur sampai dengan ujung sirip ekor bagian paling belakang. Pada bagian ekor terdapat anus, sirip dubur, sirip ekor, dan kadang-kadang juga terdapat scute dan finlet.

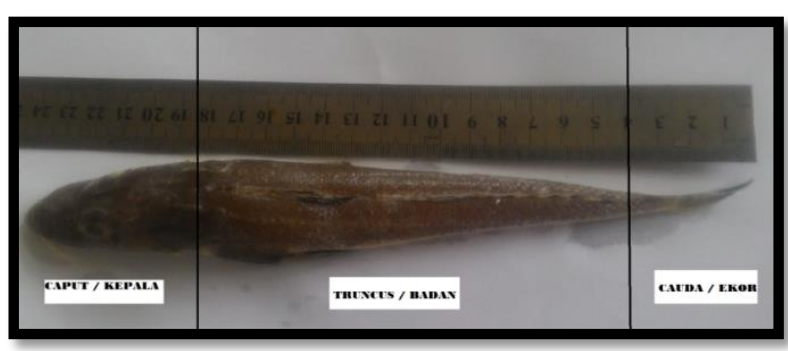

Gambar 2 Proporsi Ikan Baji - baji

Dari proporsi bagian tubuh ikan tersebut pada bagian caput, truncus, dan cauda terdapat proporsi yang berbda pada komposisi kimianya. Bagian truncus memiliki proporsi yang terbesar dibandingkan caput dan cauda, namun setiap bagian memiliki potensi untuk dapat dijadikan sumber bahan baku yang dapat diolah karena setiap bagian memiliki keunggulan tersendiri dalam komposisi kimianya.

Analisis proksimat menggolongkan komponen yang ada pada bahan pakan berdasarkan komposisi kimia dan fungsinya yaitu: air (moisture), abu (ash), protein kasar (crude protein), lemak kasar (ether extract), dan bahan ekstrak tanpa nitrogen (nitrogen free extract) (Suparjo, 2010). Analisis proksimat memiliki beberapa keunggulan yakni merupakan metode umum yang digunakan untuk mengetahui komposisi kimia suatu bahan pangan, tidak membutuhkan teknologi yang canggih dalam pengujiannya, menghasilkan hasil analisis secara garis besar, dapat menghitung nilai total digestible nutrient dan dapat memberikan penilaian secara umum pemanfaatan dari suatu bahan pangan.

Analisis makronutrien dapat dilakukan dengan analisis proksimat. Metode analisis proksimat meliputi kadar abu dengan metode pengabuan kering (dryashing) menurut AOAC 2005, kadar air dengan metode oven menurut AOAC 2005, kadar lemak dengan metode soxhlet menurut AOAC 2005, kadar protein dengan metode kjeldahl menurut AOAC 2005 dan karbohidrat dengan metode by different (Winarno, 1993 dalam Sitoresmi, 2012).

Protein berasal dari kata Yunani, yaitu Proteos yang berarti utama, istilah ini digunakan karena protein merupakan zat yang paling penting dalam setiap organisme. Protein adalah molekul makro yang mempunyai berat molekul antara lima ribu hingga jutaan gram per mol.

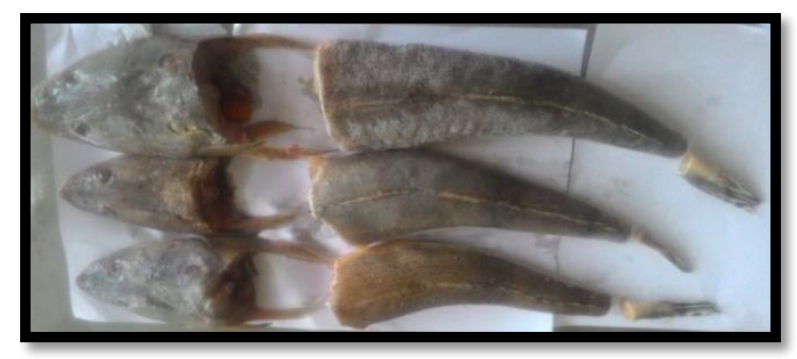

Gambar 3 Proporsi bagian Caput, Truncus, Cauda pada Ikan Baji - baji

Berdasarkan (Gambar 4) dari hasil pengujian komposisi kimia terhadap kandungan protein didapatkan nilai tertinggi pada bagian truncus yaitu $15,97 \%$ dan nilai terendah pada bagian caput yaitu $14,65 \%$.

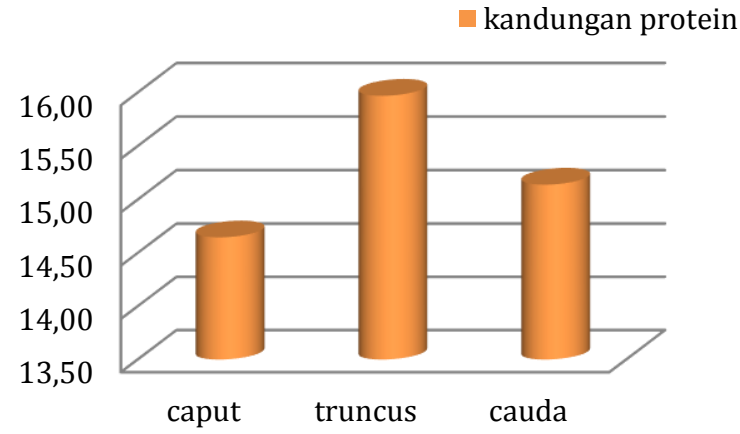

Gambar 4 Proporsi Bagian Ikan Baji - baji terhadap Kandungan Protein 
Protein berperan penting untuk pertumbuhan, karena mengandung asam amino esensial dan non-esensial. Protein merupakan sumber energi utama pada ikan, jika kebutuhan protein tidak dicukupi dalam makanannya, maka akan terjadi penurunan drastis atau penghentian pertumbuhan atau kehilangan bobot tubuh karena ikan akan menarik kembali protein dari beberapa jaringan untuk mempertahankan fungsi dari jaringan yang lebih vital. Berdasarkan literatur yang didapatkan kadar protein optimum untuk ikan adalah 25-50\%, jika dibandingkan dengan hasil analisaprotein pada pakan uji yang didapatkan kadar protein berkisar 15,37\% - 17,9\% yang berarti masih belum memenuhi kadar protein optimum untuk ikan yaitu $25-50 \%$ (Iskandar, 2017).

Dari hasil anova pada perlakuan terhadap pengujian kandungan protein hasil $\mathrm{F}$ hitung $(7,76)$ dengan nilai sig. sebesar $0,022(P<0,05)$ diketahui data tidak homogen dan terdapat perbedaan yang signifikan antar perlakuan. Nilai signifikan perbedaan antar perlakuan caput (A1) dengan truncus (A2) memiliki sig. sebesar 0,008, dan nilai signifikan antar perlakuan caput (A1) dengan cauda (A3) memiliki sig. sebesar 0,196, serta nilai signifikan antar perlakuan truncus (A2) dengan cauda (A3) memiliki sig. sebesar 0,050. Hasil nilai signifikan antar perlakuan diketahui bahwa A1 - A2 dan A2 - A3 terdapat perbedaan yang signifikan sedangkan antar perlakuan A1 A3 tidak terdapat perbedaan (homogen) terhadap pengujian kandungan proteinnya.

Lemak adalah senyawa organik yang tidak larut dalam air, namun larut dalam pelarut organik sebagai sumber energi terpenting untuk pertumbuhan dan kelangsungan hidup ikan (Rostika, 1997 dalam Iskandar, 2017).

Lemak secara kimiawi tersusun oleh sekelompok senyawa yang berbeda dalam bahan makanan lemak dapat terdiri dari dua bentuk yaitu yang tampak (visible) dan yang tidak tampak (invisible). Lemak yang tampak misalnya mentega, margarin, minyak goreng dan sebagainya. Lemak yang tidak tampak misalnya yang terdapat dalam berbagai bahan makanan seperti daging, kacang tanah, susu, telur, dan sebagainya (Sediaoetama, 2008).

Berdasarkan (gambar 5) dari hasil pengujian komposisi kimia terhadap kandungan lemak didapatkan nilai tertinggi pada bagian truncus yaitu $10,40 \%$ dan nilai terendah pada bagian cauda yaitu 2,12\%. Kandungan lemak 0,1-0,2\% nyaman dicerna dan cepat di manfaatkan oleh jaringan tubuh. Hampir semua bahan kandungan lemak adalah asam lemak esensial tak jenuh yang dibutuhkan untuk pertumbuhan dan dapat menurunkan kolesterol darah. Ikan yang berbeda di laut dan air tawar mengandung berbagai jumlah lemak, ada yang lebih berlemak dan ada yang kurang berlemak. Lemak adalah salah satu faktor utama dalam ikan, faktor lain adalah protein, vitamin, dan mineral.

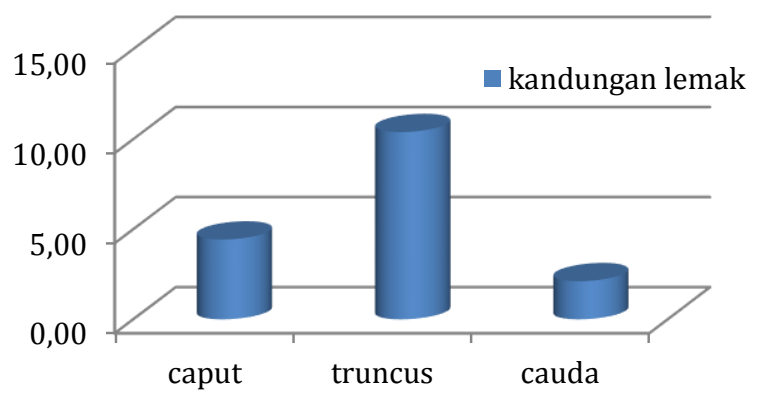

Gambar 5 Proporsi Bagian Ikan Baji - baji Terhadap Kandungan Lemak

Dari hasil anova pada perlakuan terhadap pengujian kandungan lemak hasil $\mathrm{F}$ hitung $(122,216)$ dengan nilai sig. sebesar 0,000 $(\mathrm{P}<0,05)$ diketahui data tidak homogen dan terdapat perbedaan yang signifikan antar perlakuan. Nilai signifikan perbedaan antar perlakuan caput (A1) dengan truncus (A2) memiliki sig. sebesar 0,00 , dan nilai signifikan antar perlakuan caput (A1) dengan cauda (A3) memiliki sig. sebesar 0,005 , serta nilai signifikan antar perlakuan truncus (A2) dengan cauda (A3) memiliki sig. sebesar 0,00. Hasil nilai signifikan antar perlakuan diketahui bahwa terdapat perbedaan yang signifikan antar setiap perlakuan pada kandungan lemaknya.

Air merupakan kebutuhan dari seluruh mahluk hidup. Demikian juga bakteri, bakteri merupakan air untuk berlangsungnya hidupnya komponen gizi lainnya. Sehingga semakin tinggi kadar air suatu bahan pangan, maka semakin cepat kerusakan bahan pangan tersebut akibat aktivitas bakteri semakin tinggi pula (Tapotubun, 2008).

Berdasarkan (gambar 6) dari hasil pengujian komposisi kimia terhadap kadar karbohidrat didapatkan nilai tertinggi pada bagian cauda yaitu $12,55 \%$ dan nilai terendah pada bagian truncus yaitu 7,51\%. 


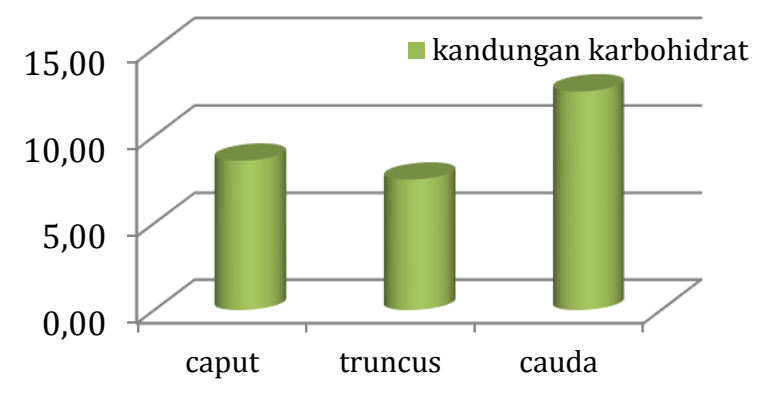

Gambar 6 Proporsi Bagian Ikan Baji - baji terhadap Kadar Karbohidrat

Berdasarkan (gambar 7) dari hasil pengujian komposisi kimia terhadap kadar air didapatkan nilai tertinggi pada bagian cauda yaitu $66,51 \%$ dan nilai terendah pada bagian truncus yaitu 63,17\%.

Pada dasarnya komposisi utama dari ikan terdiri dari air kadarnya sebanyak 66-84,0\%. Air merupakan komponen dasar ikan. Air di dalam daging ikan terdapat dua bentuk yaitu air bebas dan air terikat sangat sukar dihilangkan dari daging ikan maupun dengan cara pengeringan. Menurut Suwedja (2011), kadar air ikan sangat bervariasi, baik antar jenis yang satu dengan yang lain, antara individu dalam jenis dan bahkan antar bagian-bagian tubuh dalam satu individu. Misalnya ikan berlemak tinggi $(63,6 \%)$, ikan berlemak rendah $(77,2 \%)$, ikan kucus $(81,8 \%)$.

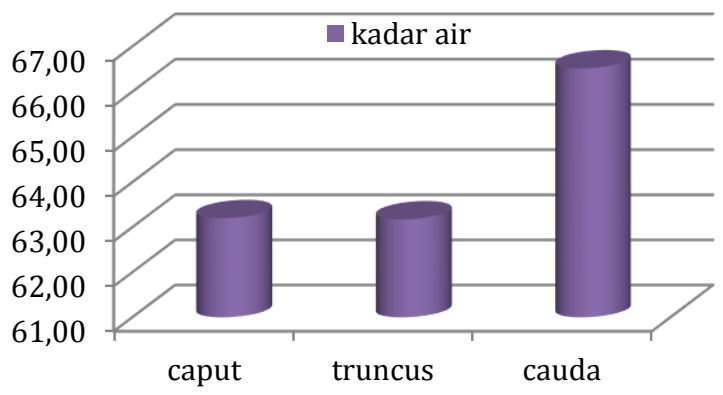

Gambar 7 Proporsi Bagian Ikan Baji - baji terhadap Kadar Air

Dari hasil anova pada perlakuan terhadap pengujian kadar air hasil $F$ hitung $(18,872)$ dengan nilai sig. sebesar $0,003 \quad(\mathrm{P}<0,05)$ diketahui data tidak homogen dan terdapat perbedaan yang signifikan antar perlakuan. Nilai signifikan perbedaan antar perlakuan caput (A1) dengan truncus (A2) memiliki sig. sebesar 0,967, dan nilai signifikan antar perlakuan caput (A1) dengan cauda (A3) memiliki sig. sebesar 0,002 , serta nilai signifikan antar perlakuan truncus (A2) dengan cauda (A3) memiliki sig. sebesar 0,02. Hasil nilai signifikan antar perlakuan diketahui bahwa A1A3 dan A2-A3 terdapat perbedaan yang signifikan sedangkan antar perlakuan A1-A2 tidak terdapat perbedaan (homogen) terhadap pengujian kadar airnya.

Kandungan air dalam bahan makanan ikut menentukan accetability kesegaran daya tahan bahan itu. Selain merupakan bagian dari suatu bahan makanan, air merupakan pencuci yang baik bagi bahan makanan tersebut atau alat-alat yang akan digunakan dalam pengolahannya. Sebagian besar dan perubahan-perubahan bahan makanan terjadi dalam media air yang ditambahkan atau berasal bahan itu sendiri (Winarno,2004). Berdasarkan (gambar 8) dari hasil pengujian komposisi kimia terhadap kadar abu didapatkan nilai tertinggi pada bagian caput yaitu $8,47 \%$ dan nilai terendah pada bagian truncus yaitu $2,61 \%$.

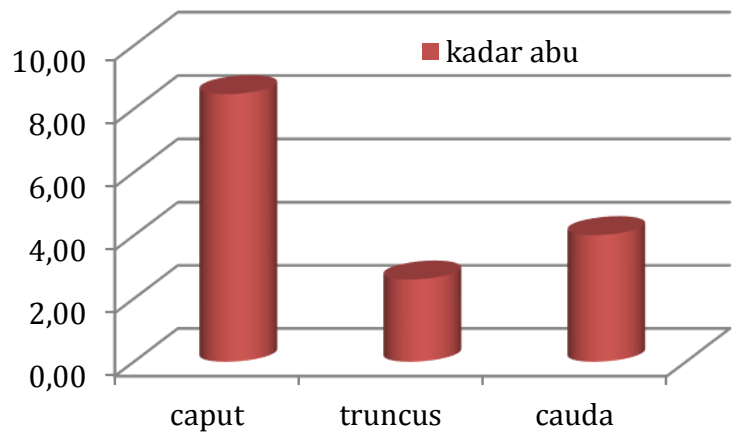

Gambar 8 Proporsi Bagian Ikan Baji - baji terhadap Kadar $\mathrm{Abu}$

Pengabuan dilakukan untuk menentukan jumlah mineral yang terkandung dalam bahan. Penentuan kadar mineral bahan secara asli sangatlah sulit sehingga perlu dilakukan dengan menentukan sisa hasil pembakaran atas garam mineral bahan tersebut. Pengabuan dapat menyebabkan hilangnya bahan-bahan organik dan anorganik sehingga terjadi perubahan radikal organik dan segera terbentuk elemen logam dalam bentuk oksida atau bersenyawa dengan ion-ion negatif. Penentuan abu total dilakukan dengan tujuan untuk menentukan baik tidaknya suatu proses pengolahan, mengetahui jenis bahan yang digunakan, serta dijadikan parameter nilai gizi bahan makanan.

Dari hasil anova pada perlakuan terhadap pengujian kadar abu hasil $\mathrm{F}$ hitung $(65,241)$ dengan nilai sig. sebesar $0,000 \quad(\mathrm{P}<0,05)$ 
diketahui data tidak homogen dan terdapat perbedaan yang signifikan antar perlakuan. Nilai signifikan perbedaan antar perlakuan caput (A1) dengan truncus (A2) memiliki sig. sebesar 0,000, dan nilai signifikan antar perlakuan caput (A1) dengan cauda (A3) memiliki sig. sebesar 0,000, serta nilai signifikan antar perlakuan truncus (A2) dengan cauda (A3) memiliki sig. sebesar 0,039. Hasil nilai signifikan antar perlakuan diketahui bahwa A1-A2, A1-A3, dan A2-A3 terdapat perbedaan yang signifikan antar setiap perlakuan terhadap pengujian kadar abunya.

\section{Peningkatan Potensi Ikan Baji-baji dibanding Ikan Komersil Lainnya}

Berbagai banyak cara yang digunakan untuk menentukan kualitas bahan baku pangan. Secara garis besar penentuan kualitas dapat dilakukan secara fisik, kimia dan biologis. Seorang ahli kimia dalam menentukan kualitas bahan makanan akan mempertimbangkan kualitas bahan baku dari segi kandungan protein, lemak atau kandungan zat makanan lainnya. Seperti halnya seorang ahli nutrisi mereka selanjutnya akan memikirkan juga kualitas makanan berdasarkan biologis seperti antara lain kecernaaannya dan nilai biologis lainnya.

Dalam perbandingan kandungan gizi, ikan tuna tergolong ke dalam ikan dengan protein yang sangat tinggi dan lemak rendah. Ikan tuna dan tenggiri memiliki kadar protein, lemak, abu, dan karbohidrat yang relatif sama kecuali kadar air pada tenggiri yang lebih banyak dari tuna. Ikan tenggiri mudah mengalami kemunduran mutu karena komposisi kimia tersebut dapat mengalami perubahan. Kemunduran mutu ikan meliputi perubahan fisik, kimia, dan organoleptik dengan urutan mulai dari prerigor, rigormortis, aktivitas enzim, aktivitas mikroba, oksidasi lemak, dan hidrolisis.

Jenis ikan yang mengandung protein tinggi yaitu tuna, tenggiri, kurisi, dan jenis ikan laut lainnya (cod, coalfish, haddock, red fish, catfish, plaice, halibut, ling, tosrk, dan mackerel). Ikanikan tersebut sangat komersil dan termasuk jenis ikan kualitas eksport yang sangat diminati karena rasa dan rupa yang menarik.

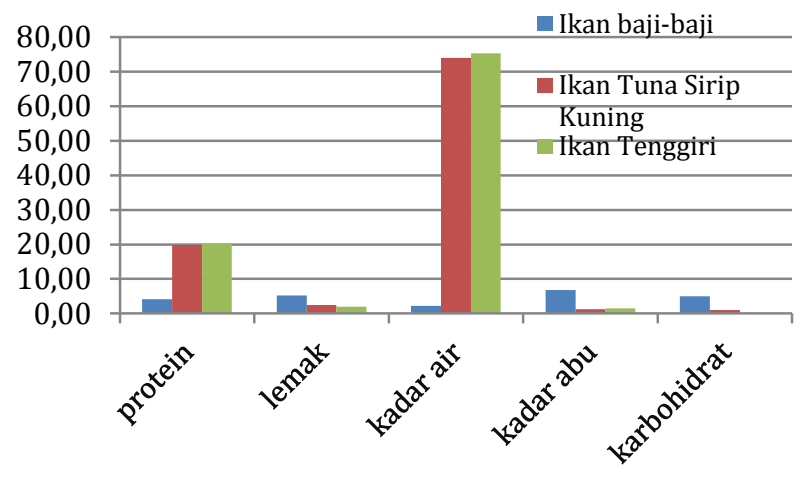

Gambar 9 Kandungan Gizi Ikan Tuna Sirip Kuning (Wahyuni, 2011), Ikan Tenggiri (Purwaningsih, 2010), dan Ikan Baji-baji

Berdasarkan penilaian kandungan gizi, ikan baji-baji memiliki nilai yang lebih unggul dari tuna dan tenggiri. Ditinjau dari penilaian protein ikan baji-baji lebih sedikit, namun unggul dalam kadar lemak, abu, dan karbohidrat. Kandungan kadar air ikan baji-baji lebih sedikit dari tuna dan tenggiri. Air merupakan sumber komponen penting dalam bahan makanan yang dapat mempengaruhi penampakan, tekstur dan cita rasa makanan. Kadar air dalam bahan makanan ikut menentukan kesegaran dan daya awet bahan makanan tersebut (Winarno, 2004).

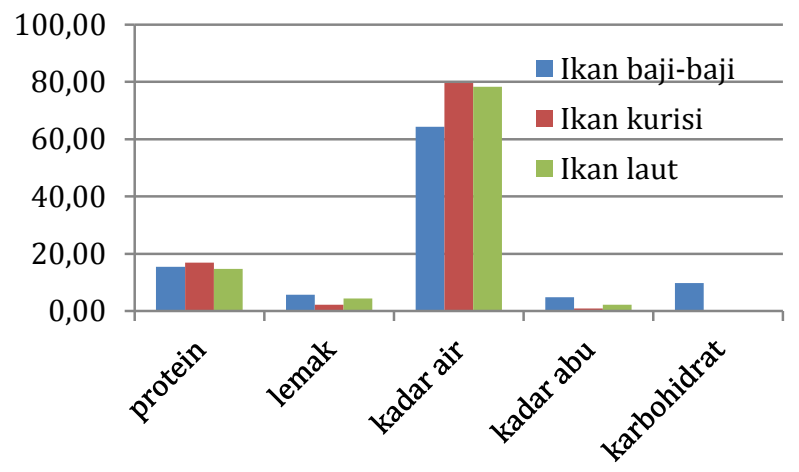

Gambar 10 Kandungan Gizi Ikan kurisi, Ikan Laut (Huda, 2003), dan Ikan baji-baji

Menurut Pertiwi (2015) keanekaragaman hasil ikani tersebut dapat memberikan suatu nilai tambah bagi masyarakat bila dipasarkan baik dalam bentuk segar, olahan setengah jadi ataupun olahan dalam bentuk jadi. Bahan baku yang dapat digunakan dalam proses pengolahan ikan adalah ikan baji-baji. Ikan tersebut dapat digunakan oleh pelaku pasar dengan mengubahnya menjadi produk makanan setengah jadi atau dalam bentuk jadi. Ikan komersil yang memiliki kandungan gizi yang tinggi yaitu kurisi, ikan laut (10 jenis terbaik 
menurut sikorski dalam Huda (2003), ikan gabus dan bandeng.

Berdasarkan kandungan gizinya ikan bajibaji lebih unggul dari ikan kurisi dan ikan laut lainnya terhadap kadar lemak, abu, dan karbohidrat. Kandungan protein ikan erat sekali kaitannya dengan kandungan lemak dan air. Ikan yang mengandung lemak tinggi rata-rata memiliki nilai protein dalam jumlah tidak besar. Daging ikan memiliki sedikit sekali tenunan pengikat (tendon) sehingga sangat mudah dicerna oleh enzim autolisis. Hasil autolisis tersebut menjadi media yang cocok untuk pertumbuhan mikroorganisme (Adawyah, 2006).

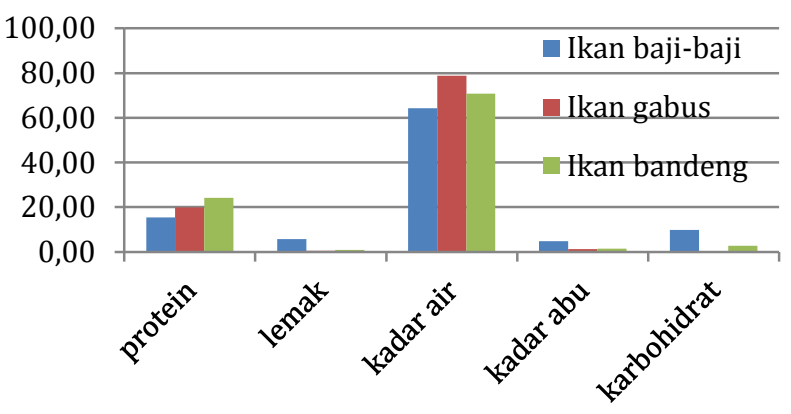

Gambar 11 Kandungan Gizi Ikan gabus (Chasanah, 2015) dan Ikan bandeng (Hafiludin, 2015) dan Ikan baji-baji

Ditinjau dari kandungan gizi protein pada ikan gabus dan bandeng. Ikan baji-baji lebih unggul dalam kandungan lemak, abu, dan karbohidrat. Tingginya kandungan lemak memiliki potensi untuk mengandung asam lemak esensial karena hanya diperoleh pada ikan yang mengandung lemak tinggi. Abu termasuk dalam data dasar zat gizi sebagai salah satu komponen proksimat dalam pangan. Ikan baji-baji unggul dalam nilai kadar abu. Pada kadar abu menyediakan sebuah perkiraan kandungan total mineral pangan. Mineral dalam abu berada dalam bentuk logam oksida, fosfat, nitrat, sulfat, klorida dan halida lainnya.

\section{KESIMPULAN}

Ikan baji-baji merupakan ikan yang kurang diminati karena memiliki rupa yang jelek dan bau amis. Perlu adanya upaya dalam peningkatan potensi ikan baji-baji melalui kandungan gizi tinggi dan protein yang lengkap serta penting untuk tubuh. Zat gizi utama pada ikan antara lain protein, lemak, vitamin dan mineral. Adapun hasil pengkajian yang dilakukan yaitu ikan baji-baji memiliki kandungan kadar air $64 \%$, protein 15\%, kadar lemak 6\%, kadar abu 5\%, dan karbohidrat 10\%. Proporsi bagian tubuh ikan baji - baji seperti pada tubuh ikan umumnya terbagi tiga bagian yaitu 1. Caput / bagian pada kepala, 2. Truncus / bagian badan, dan 3. Cauda / bagian ekor. Perbadingan proporsi bagian tubuh pada komposisi kimia terhadap kandungan protein didapatkan nilai tertinggi pada bagian truncus yaitu 15,97\% dan nilai terendah pada bagian caput yaitu $14,65 \%$. Kandungan lemak didapatkan nilai tertinggi pada bagian truncus yaitu $10,40 \%$ dan nilai terendah pada bagian cauda yaitu 2,12\%. Kadar karbohidrat didapatkan nilai tertinggi pada bagian cauda yaitu $12,55 \%$ dan nilai terendah pada bagian truncus yaitu $7,51 \%$. Kadar air didapatkan nilai tertinggi pada bagian cauda yaitu $66,51 \%$ dan nilai terendah pada bagian truncus yaitu $63,17 \%$. Kadar abu didapatkan nilai tertinggi pada bagian caput yaitu $8,47 \%$ dan nilai terendah pada bagian truncus yaitu 2,61\%. Dari peningkatan potensi ikan baji-baji ini memiliki kandungan gizi yang hamper sama dengan kandungan gizi ikan komersil lainnya.

\section{UCAPAN TERIMAKASIH}

Karya ini didukung secara finansial oleh Kementerian Riset, Teknologi, dan Pendidikan Tinggi Republik Indonesia melalui Penelitian Dosen Pemula (PDP) 2018. Para penulis berterima kasih kepada seluruh civitas akademika Program Studi Teknologi Pengolahan Hasil Perikanan Politeknik Tanjungbalai.

\section{DAFTAR PUSTAKA}

Anjarsari, Bonita. 2010. Pangan Hewani (Fisiologi Pasca Mortem dan Teknologi). Bandung: Graha Ilmu.

Adawyah, R. 2006. Pengolahan dan Pengawetan Ikan. Jakarta: Bumi Aksara.

AOAC. 2005. Official Methods of Analysis. Association of Official Analytical Chemists. Benjamin Franklin Station, Washington.

Asfar, Muh., Tawali, A. B., dan Mahendradatta, M. 2014. Potensi Ikan Gabus (Channa striata) Sebagai Sumber Makanan Kesehatan. SNTI-B13 Prosiding Seminar Nasional Teknologi Industri II. ISBN: 978602-14822-1-6

Badan Pusat Statistik Kota Tanjungbalai. 2017. Produksi Perikanan menurut Asal Tangkapan di Kota Tanjungbalai (Ton) 2010-2017. 
https://tanjungbalaikota.bps.go.id/ dynamictable/2017/07/12/110/produks i-perikanan-menurut-asal-tangkapan-dikota-tanjungbalai-ton-2010-2017.html.

Diakses tanggal 1 agustus 2018

Chasanah, Ekowati., Nurilmala, M., Purnamasari, A. R., dan Fathriani, D. 2015. Komposisi Kimia, Kadar Albumin Dan Bioaktivitas Ekstrak Protein Ikan Gabus (Channa Striata) Alam Dan Hasil Budidaya. JPB Kelautan dan Perikanan. 10(2): 123-132.

Gandotra R, Sharma A, Koul M, Gupta S. 2012. Effect of Chilling and Freezing on Fish Muscle. IOSR Journal of Pharmacy and Biological Sciences (IOSRJPBS). 2(5): 5-9.

Hafiludin. 2015. Analisis Kandungan Gizi Pada Ikan Bandeng Yang Berasal Dari Habitat Yang Berbeda. Jurnal Kelautan. 8(1): 3743.

Harianti. 2011. Ikan Gabus (Channa striata) dan berbagai Manfaat Albumin Yang Terkandung di Dalamnya. Jurnal Balik Diwa. 2(1): 18-25

Huda, Nurul. 2003. Komposisi Asam Amino dan Mutu Protein Ikan Kerisi (Nemipterus japonicus). publication at: https://www.researchgate.net/publicatio $\underline{n} / 281550409$

Iskandar, Rina dan Fitriadi, S. 2017. Analisa Proksimat Pakan Hasil Olahan Pembudidaya Ikan di Kabupaten Banjar Kalimantan Selatan. Jurnal Ziraa'ah. 42(1): 65-68.

Metro Asahan. 2017. Ikan dari Tanjungbalai Diekspor ke Malaysia, Per Hari Capai 12 Ton https://www.metroasahan.com Lekonomi/2017/03/25/13070/ikandari-tanjungbalai diekspor-ke-malaysiaper-hari-capai-12-ton/ Diakses tanggal 1 agustus 2018

Nurjanah., Abdullah, A., Kustiariyah. 2011. Pengetahuan dan Karakterisasi Bahan Baku Hasil Perairan. Bogor: IPB Press

Pamijiati. 2009. Pengaruh Ekstrak Daun Selasih (Ocimum basilicum linn) Terhadap Mutu Kesegaran Ikan Bandeng Selama Penyimpanan Dingin (Chanos chanos Forsk). [Skripsi]. Semarang: Universitas Diponegoro

Pertiwi, K. A., Affandi, M. I., dan Kasymir, E. 2015. Nilai Tambah, Pengendalian Persediaan Bahan Baku Dan Pendapatan Usaha Pada Kub Bina Sejahtera Di Kelurahan Kangkung Kecamatan Bumi
Waras Kota Bandar Lampung. JIIA. 3(1): 26-31.

Purwaningsih, Sri. 2010. Kandungan Gizi dan Mutu Ikan Tenggiri (Scomberomorus commersonii) selama Transportasi. Seminar Nasional Perikanan Indonesia. Sekolah Tinggi Perikanan.

Sediaoetama AD, 2008. Ilmu Gizi untuk Mahasiswa dan Profesi. Jakarta: Dian Rakyat.

Sitoresmi dan Kadesti, M. A. 2012. Pengaruh Lama Pemanggangan Dan Ukuran Tebal Tempe Terhadap Komposisi Proksimat Tempe Kedelai. [Skripsi]. Universitas Muhammadiyah Surakarta.

Suparjo, P. 2010. Reposisi Tanaman Pakan dalam Kurikulum Fakultas Peternakan. Lokakarya Nasional Tanaman Pakan Ternak

Suwedja. 2011. Biokimia Hasil Perikanan. Jakarta: Media Prima Aksara.

Tapotubun, A. M., Nanloty, EEE.M, \& Louhenapesy. 2008. Efek Waktu pemanasan Terhadap Mutu Beberapa Jenis Ikan. Ichthyos. 7(2): 65 - 70.

Wahyuni, Sri. 2011. Histamin Tuna (Thunnus,sp) dan Identifikasi Bakteri Pembentuknya pada Kondisi Suhu Penyimpanan Standar. [Skripsi]. Institut pertanian bogor.

Winarno FG, 2004. Kimia Pangan dan Gizi. Jakarta: PT Gramedia Pustaka. 